Streib,H., Dinter,A. \& Söderblom,K. (eds) (2008): Lived Religion -

Conceptual, Empirical and Practical-Theological Approaches. Essays

in Honor of Hans-Günter Heimbrock, Leiden: Brill.

\title{
MORE SPIRITUAL THAN RELIGIOUS: CHANGES IN THE RELIGIOUS FIELD REQUIRE NEW APPROACHES
}

\author{
Heinz Streib
}

'Lived religion' signifies a shift of focus - from the institutionalized forms of beliefs and practices to a more precise focus of attention on the religiosity of the people, of individuals and groups as embedded in the contexts of life-worlds and biographies. Thus, 'lived religion' includes attention for beliefs and practices which may not be in accord with the official teachings of religious traditions. 'Lived religion' may dwell in sub-currents of religious organizations, or flourish outside organized religion. In our Western cultures the self-identification of "being spiritual" is one of the increasingly popular ways of expressing an individual - and eventually unconventional - form of religiosity or the search for it. In this article, we focus on the "spiritual" self-identification: We will discuss the problem of a theoretical framework for understanding "spirituality," we summarize extant empirical results and present our own empirical findings, and we conclude with a prospect on future research.

\section{Spirituality - Conceptual Clarifications}

In the first place we consider "spirituality" to be the self-identification of research participants and not a scientific concept. ${ }^{1}$ Thus, we do not start with a discussion of the various recent attempts of defining 'spirituality'. On the contrary, we have strong reservations against the latest fashion in the social sciences of promoting 'spirituality' as a supplement or substitute for 'religion' and 'religiosity'. It is a waste of time to re-invent the wheel and, at the same time, to ignore centuries of highly sophisticated discourse about the concepts of 'religion' and

\footnotetext{
${ }^{1}$ In this text, "spirituality" in double quotation marks indicates self-identification of research participants, while 'spirituality' in single quotation marks refers to the concept.
} 
'faith' in philosophy, theology, religious studies, and the social sciences. And in favor of our intent of including the contemporary spiritual quest into the concept of 'religion', we are in the position of referring to a large number of proposals for conceptualizing un-churched or de-institutionalized (Streib 2007b) forms of religion, some of which suggest the use of adjectives such as invisible (Luckmann 1967; Knoblauch 2003) or implicit (Thomas 2001), some re-conceptualize 'faith' in contrast to 'religion' and 'belief' (Smith 1963; 1979). To suggest another conceptual avenue of including the spiritual quest into the concept of religion: Psychology of religion would stand itself on solid ground by re-considering Schleiermacher's (1799) definition of religion as "sensibility and taste for the infinite" - which Schleiermacher, in his third speech, beautifully explicated by his appreciation and fascination for the "longing of young minds for the miraculous and supernatural" and their openness for "every trace of another world" as "the first stirring of religion" (Schleiermacher 1799, 59). Here we encounter a (pre-psychology, pre-evolution theory, pre-phenomenology) approach to a comprehensive conceptualization of religion - in true phenomenological manner.

In an article like this there is not enough space to develop and justify a comprehensive theory of 'religion' (including 'spirituality'), but the task here is to indicate the conceptual frame for research on "spirituality". And it is my suggestion to work with the term 'lived religion.' This term, is a good starting point and provides a basic conceptual framework for understanding and researching the contemporary "spirituality" and spiritual quest. 'Lived religion' decisively suggests taking the religious self-understanding of the people on the street, everyday religion (Streib 1998), as point of departure for reflection and research (Dinter, Heimbrock \& Söderblom 2007).

Thus, we approach "spirituality" as part of 'lived religion'. The basic thesis is this: "Spirituality" can be fully explicated in the conceptual framework of 'religion'-including however clear and special attention to life-world and biography, but also to the experiential dimension and inward orientation of religiosity. "Spirituality" requires no brand-new approaches of conceptualization, but a re-reading and re-considering of what the theory of religion has to offer. The second part of this initial thesis says: "Spirituality" is 'lived religion' which, in part and by an increasing number of people, is lived outside traditional religions. This second part of the thesis, however, indicates even more irrefutably the 
need for attention on context, thus the necessity for taking into account the expertise of sociology.

\section{Spirituality and Mysticism - A Sociological Perspective}

From the early days of sociology, we have derived an influential distinction regarding the organization of religion: the distinction between church and sect, introduced and explicated by M. Weber and by E. Troeltsch. In the meantime, this distinction plays a role not only in the sociology of new religious movements - even though the terminology has changed, since we avoid the term 'sect' in favor of 'new religious movements;' the church-sect distinction has become one of the basic tools for understanding religion in sociological terms and for constructing the religious field, as we can see in Bourdieu's (1971; 1987) work - which presents one of the most advanced contemporary approaches to the sociology of religion.

What has been widely ignored, but is the longer the more "necessary and adequate" (Daiber 2002, 329), is a reminder that Troeltsch (1911; 1912) talks about three types; and his third type he called mysticism. Thus, aside from the ideal types of church religion and sect religion (which both, within their realms, may embrace and nurture a kind of mystical or spiritual inward orientation), Troeltsch identifies mysticism as the type of Protestant religion that features religious individualism, develops outside of church and sect, and has no external organization (Daiber 2002, 335). R. Hood (2006) is right with his reference to Troeltsch's third type of religion as an identification of a form of religion which is an alternative to, and stands in contrast to, church religion and sect religion and which in contemporary empirical research can be identified by questions that elicit a "spiritual, but not religious" self-identification - and supposedly by scales measuring mysticism such as the Mysticism Scale (Hood 1975).

Certainly, Troeltsch's early identification of religious individualism, including the variant of mysticism as a third ideal type, was thoughtful and perhaps ahead of his time. We witness today a global spread of just this kind of religious individualism. The problem with Troeltsch's expertise is that he talks about mysticism in Protestantism and rather in a historical perspective - which means that today we need some evidence of its contemporary and cross-religious validity. Second, there is a problem with sociological plausibility: Troeltsch himself appears 
somewhat unclear about whether mysticism is a religion without any organization or whether it develops at least some organizational structures. Also this second question calls for more contemporary sociological clarification.

Perhaps Bourdieu's (1987) vector structure in the religious field which he developed in relation to Weber's work and which includes, besides the priest and the prophet, also the magician is a starting point - but only, if we take the difference between Weber's / Bourdieu's magician and Troeltsch's mystic into account and if we find ways of an adequate sociological description of the contemporary "spiritual" field. In sociology, we have a number of proposals for characterizing social units which are neither institutions nor organizations - in terms of milieu, network, or scene (Gebhardt 2002). This, of course, needs to be developed further as culture changes, including increasing individualization, migration, social mobility, internet use and the like. Bourdieu's characterization of the religious field, nevertheless, sets the stage for a sociological analysis of contemporary "spirituality:" The competition for influence and customer attraction, for the best interpretation of the world and for the most helpful advice including body, soul and spirit to live a good life on this earth are still constituting the dynamics and the "rules of the game" in the religious field. But the market structures have changed: monopolists, small entrepreneurs, shopkeepers and even street traders have got strong competitors in form of supermarkets and internet shops.

For our discussion and for research about "spiritual" self-identification, this brief sociological inquiry suggests two things: Apart from the kind of spirituality which has for centuries been part of Christian religiosity, there is spirituality outside the domains of the priest and the prophet, outside organized religion. This spirituality, even outside organized religions, is part of the religious field - which can be researched empirically.

\section{Some Research Results on Contemporary Spirituality}

Though in general they rightly state that "there are embarrassingly few studies that systematically map the worldviews of the unchurched," Houtman and Aupers (2007) present longitudinal results about the spread of people who associate themselves with a spiritual worldview: They witness a trend toward what they call "post-Christian spiritual- 
ity" in two decades in most of the 14 countries for which they have re-analyzed the huge amount of World Value Survey data $(\mathrm{n}=61,352)$ in a sophisticated (and generally plausible) procedure. Based on a selection of questions such as about the image of God (personal God; some sort of spirit or live force; etc.), New Age affinity, disagreement with traditional Christian beliefs, but simultaneous disagreement with secular rationalism, this re-analysis reveals a clear trend in most of these countries, especially France, Great Britain, the Netherlands and Sweden, which is associated with the decline of traditional moral values and with cohort replacement. But all of the survey data taken together do not allow to exactly quantify the emigration from organized religion(s) to the new segments in the religious field that are characterized by a "spiritual" or "more spiritual" self-identification.

There are, however, some other attempts to quantitatively assess the amount of people who associate with "spirituality". As a relatively simple, but nevertheless effective tool for identifying "spirituality" with some precision, a set of four questions has been designed and used in empirical research: Are you "religious but not spiritual," "spiritual but not religious," "religious and spiritual" or "neither religious nor spiritual." For the U.S.A. we have data from a considerable body of research in which the spirituality question has been asked. From a number of studies we have evidence that there are between $18 \%$ and $20 \%$ who self-identify as being "spiritual, but not religious" (Marler \& Hadaway 2002). In Figure 1 results of these studies are visualized and placed side by side to allow comparison.

For Germany, the Religionsmonitor (Bertelsmann-Stiftung) for the first time in German survey history included a self-rating scale for spirituality next to a self-rating scale for religiosity. The combination of both selfrating scales allows for an assessment of "more spiritual than religious" self-identifying participants and distinguishing them from the other groups. These results are presented in Figure 2. They reflect not only the relatively high number of secular self-identifications among church members in the German Protestant (33.4\%) and Roman-Catholic $(30.2 \%)$ churches, but also for the first time in a sample representative for the general population, the segment of "more spiritual" self-identifications: $10.1 \%$ in the Protestant churches, $8.7 \%$ in the Roman-Catholic Church, 5.3\% in the Protestant "free churches" (e.g. Methodist Church) and $16.7 \%$ in other Christian traditions (such as Orthodox Church, Pentecostal and charismatic groups). Taken together, we count $9.3 \%$ members of a Christian religious organization (including all denominations, 

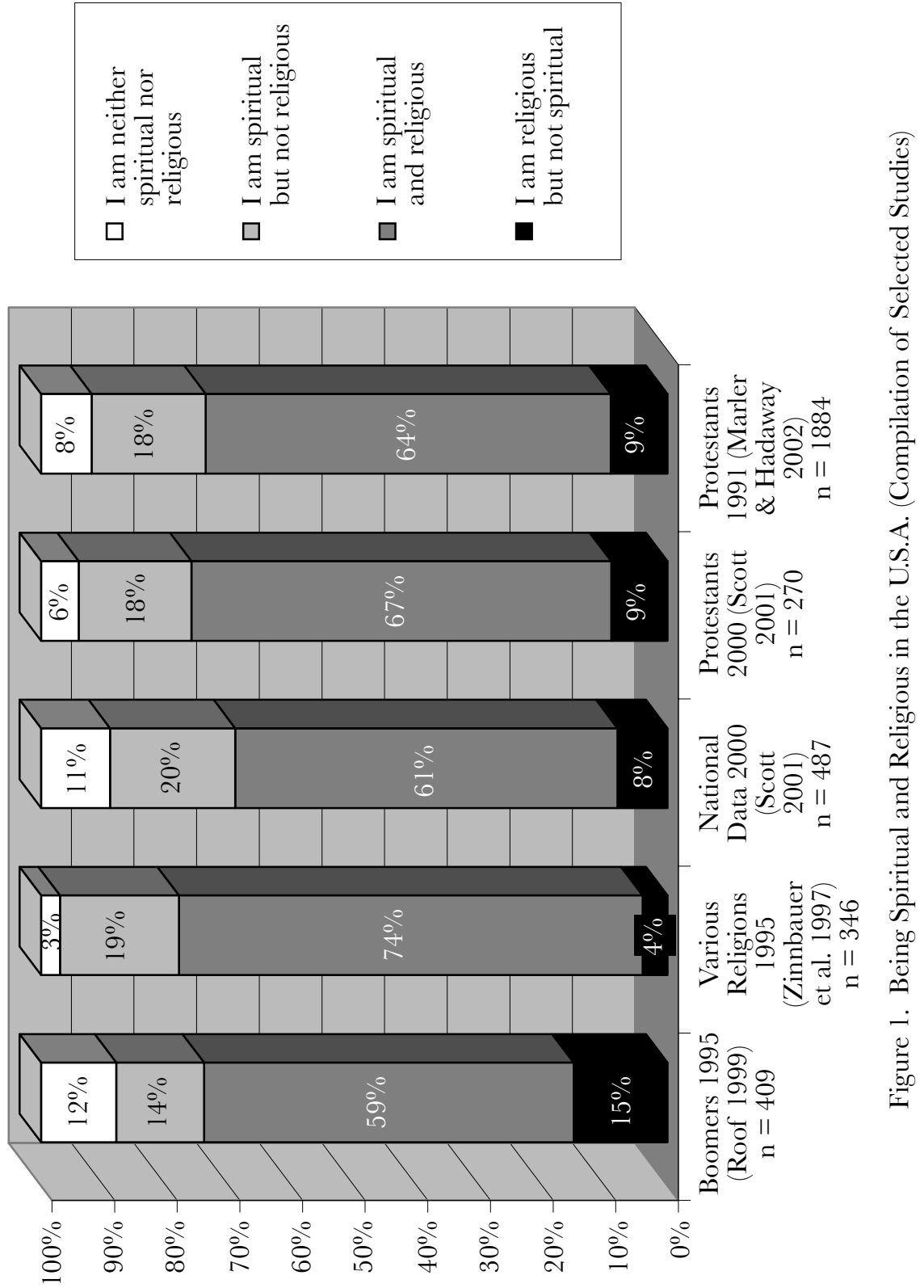


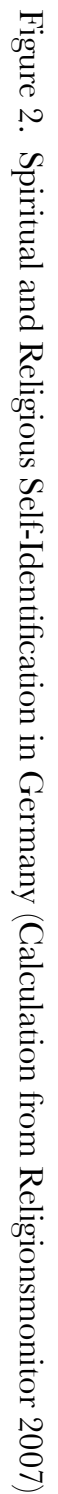
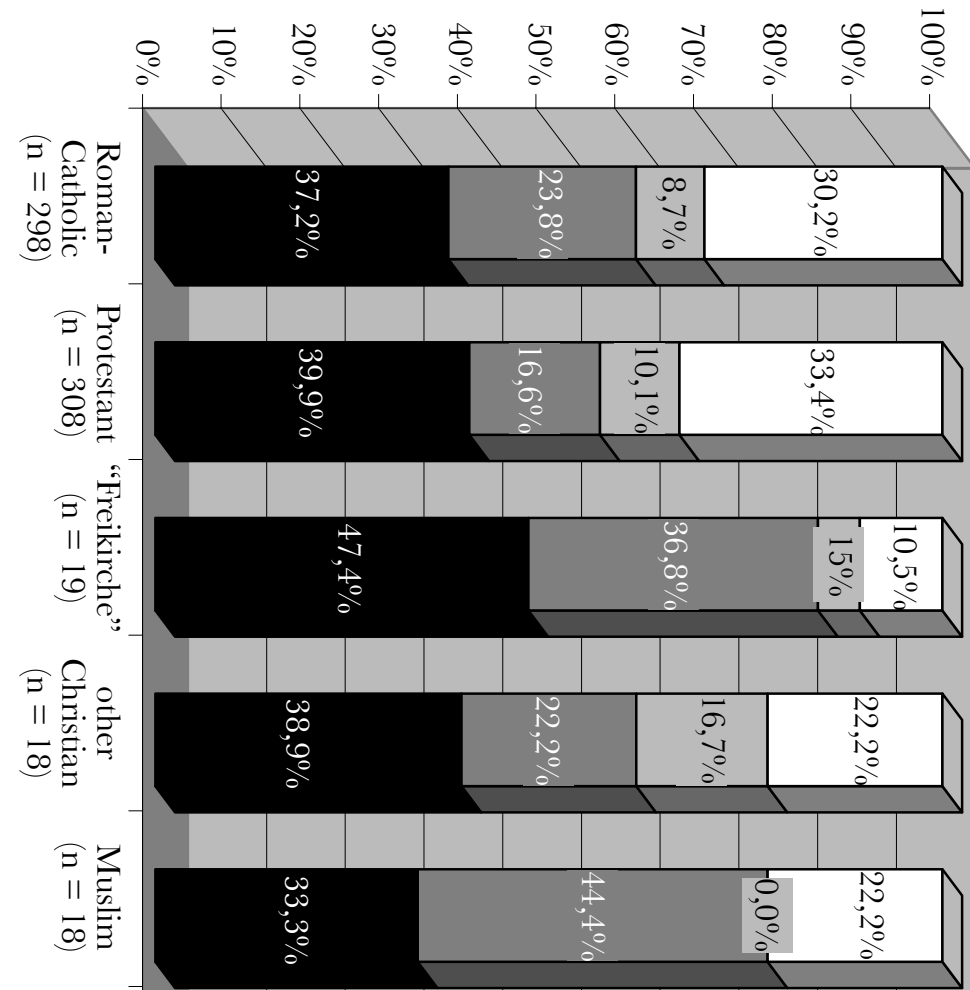

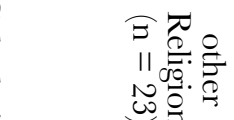

兀

ध
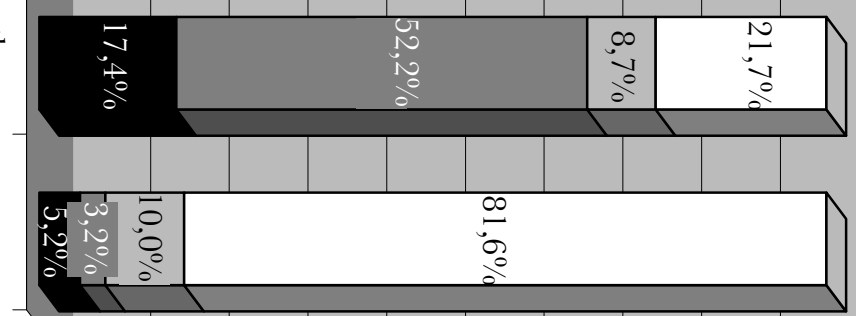

\begin{tabular}{|c|c|c|c|}
\hline $\boldsymbol{\square}$ & $\square$ & $\square$ & $\square$ \\
\hline 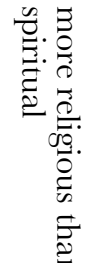 & 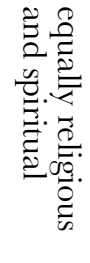 & 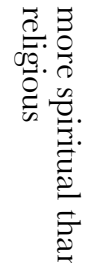 & 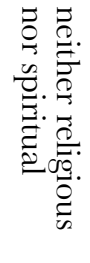 \\
\hline
\end{tabular}


these are $68.7 \%$ of the population) who can be identified as being "more spiritual than religious". Surprisingly, there are $10.0 \%$ who have no religious affiliation at all, but self-identify as being "more spiritual than religious" - and to the group without religious affiliation belong $26.2 \%$ of the German population.

We can conclude from statistical data that in Germany, almost regardless of whether they are members of a religious organization, about $10 \%$ identify as being "more spiritual than religious," while in the U.S.A. we have about $20 \%$ members in religious organization who self-identify as "spiritual, but not religious." Furthermore we have evidence for both religious fields from Houtman \& Auper's re-analysis of a modest (U.S.A.) or recognizable (Germany) longitudinal trend of an increase of post-Christian spirituality over two decades from 1980 to 2000 which, as the authors claim, can be ascribed to cohort replacement.

\section{"More Spiritual" Self-Identification and Deconversion}

Now we present results from our own research in Germany and U.S.A. The data are taken from the Bielefeld-Based Cross-Cultural Study on Deconversion which was completed in 2005 and included a total $\mathrm{N}$ of 1,197 research participants (Streib 2007a; Keller, Csöff, \& Streib 2007). It should be noted, however, that our data set is not representative for the general population, but includes only members $(\mathrm{n}=1,067)$ or former members (i.e. deconverts, $\mathrm{n}=130$ ) of religious organizations with an intended rather strong over-representation of members in new religious fundamentalist (oppositional) and small church (accommodating) organizations; thus mainline religious organizations represent less than $50 \%(\mathrm{n}=501)$ of our data. In our questionnaire we asked the question: "Mark the statement which most identifies you: I am more religious than spiritual. I am more spiritual than religious. I am equally religious and spiritual. I am neither religious nor spiritual."

As Figure 3 shows, our results appear to reveal surprisingly high numbers of people who self-identify as being "more spiritual than religious." For deconverts and intradition members in Germany taken together we count $20.6 \%$ "more spiritual" subjects; for the U.S.A. we count $39.3 \%$. Compared to results from the surveys, this appears double and the difference calls for an explanation. Apart from the structure of our sample with an under-representation of mainline religions, we can point out for the U.S.A., to a difference in asking our question ("more ...than..." 
in our research, "not..., but..." in the other surveys) and to a time difference of one decade or more. For the German situation we should add that, when separating out the mainline members, the percentage of "more spiritual" respondents in our data drops to $13.2 \%$ and thus the difference can be seen as within tolerance. Taken together, our results for the members of religious organizations are roughly in line with and confirm the trend as indicated in the surveys - with an open question for the situation in the U.S.A.

A surprise to us, however, are the deconverts: The deconverts' preference for the self-identification as being "more spiritual than religious" almost doubles, as Figure 3 shows. This result can be confirmed by a closer look at the deconversion avenues: ${ }^{2}$ In our sample we have, among 101 deconverts, 29 who take a secular exit; they appear to terminate concern with religious belief altogether. The number of deconverts who exit the field of organized religion, however, is far greater: there are 24 deconverts who terminate affiliation, but continue practicing their religiosity in private; also there is another group of 9 deconverts who after disaffiliation engage in a kind of patchwork religion. Thus almost two third of our deconverts leave the field of organized religion. If we then take into account how these deconverts have self-identified in terms of spirituality or religion, it is interesting, but not so surprising that a majority of 15 out of 24 privatizing defectors self-identify as "more spiritual;" and even less surprising it is for the 5 out of 9 heretical defectors. But there are 8 out of 29 secular "exiters" who self-identify as "more spiritual." Taken together, 28 out of 62 - or almost $50 \%$ - of the deconverts who leave organized religion self-identify as being "more spiritual." Here we are able to identify and shed some light on a segment of the religious field which has been overlooked in previous research: spirituality outside the domains of the priest and the prophet, spiritual quest outside organized religion. No wonder, therefore, that the number of "more spiritual" self-identification is significantly higher among deconverts.

\section{What Does "Spirituality" Signify?}

When we ask what "spirituality" signifies, we nota bene adhere to the meaning that our respondents give to their self-identification. On the

\footnotetext{
${ }^{2}$ Deconversion trajectories were assessed in qualitative interpretation of narrative interviews with deconverts and then imported into the SPSS data.
} 

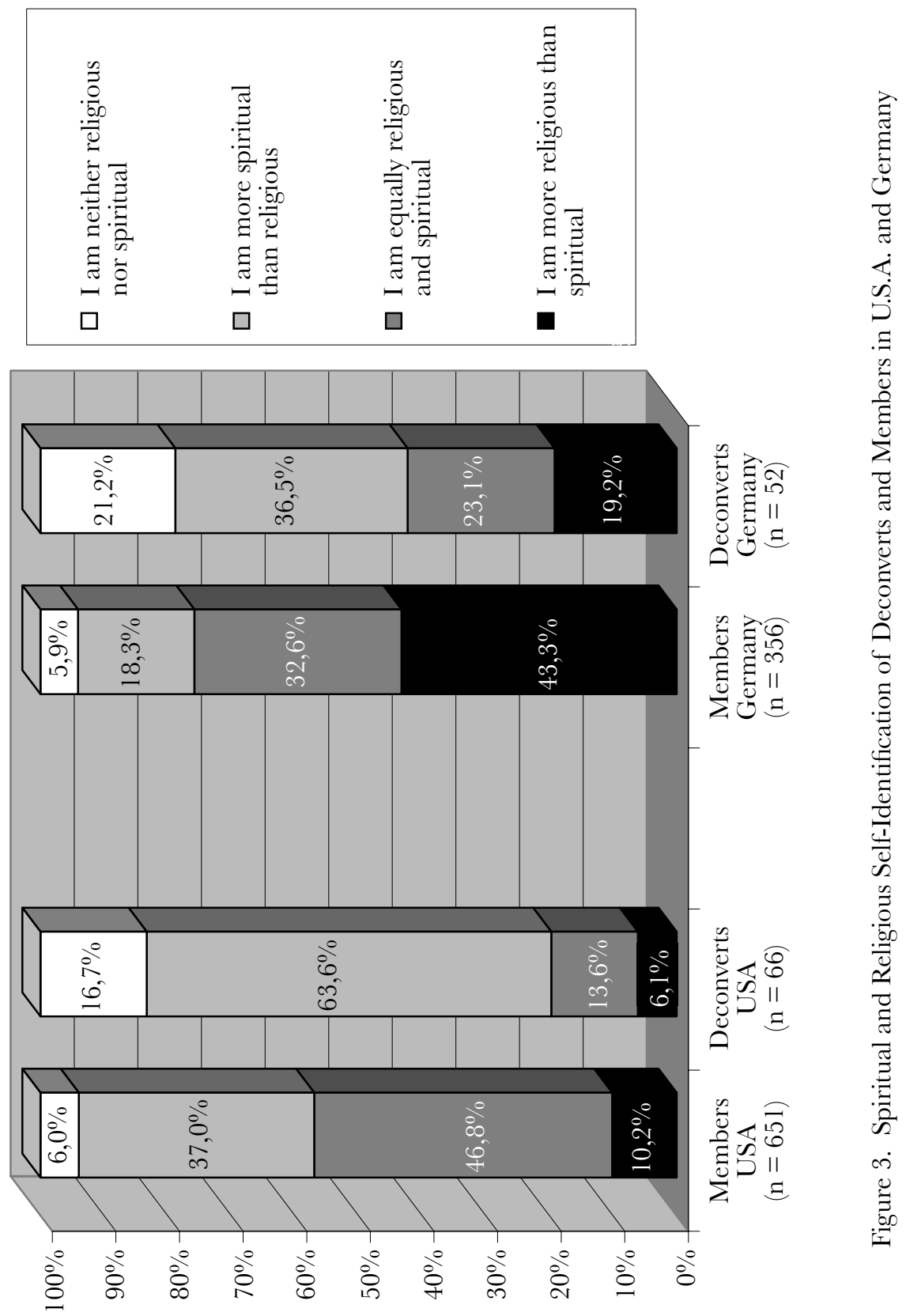
basis of our data, we have two ways of giving some indication about what is meant by "spirituality:" one quantitative, the other qualitative.

The quantitative avenue is Multiple Analysis of Variance (MANOVA) using a number of psychometric measures in relation to the four groups generated on the basis of spiritual/religious self-identification. From Post Hoc Tests we derive the results that "more spiritual" self-identification, in comparison to "more religious" self-identification, goes hand in hand with...

- greater Openness for Experience (mean difference for members $(\mathrm{n}=1,001): .18^{*} ;$ for deconverts $\left.(\mathrm{n}=118): .57^{*}\right),{ }^{3}$ as measured by the Big Five personality instrument (Costa \& McCrae, 1985);

- greater Personal Growth (mean difference for members $(n=1,003)$ : $.20^{*}$; for deconverts $\left.(\mathrm{n}=118): .51^{*}\right)$, as measured by the Ryff scale for Psychological Well-Being (Ryff \& Singer, 1996);

- lower Authoritarianism (mean difference for members $(\mathrm{n}=993)$ : $-.13^{*}$; for deconverts $(\mathrm{n}=115)$ : $\left.-.42^{*}\right)$, as measured by the RightWing Authoritarianism Scale (Altemeyer, 1996);

- higher scores in Xenosophia or readiness for inter-religious dialog (mean difference for members $(\mathrm{n}=743)$ : .22*; for deconverts $(\mathrm{n}=$ 55): .22), as measured by our new scale for religious styles.)

- lower scores on absoluteness of religious truth claims (mean difference for members: $-.22 *$; for deconverts: -.49 ), as measured by the scale 'Truth of Texts and Teachings' of our new scale.

Furthermore, we see higher scores in the ratings of the Faith Development Interviews of the "more spiritual" respondents opposed to the "more religious" respondents in the German sample ( $\mathrm{n}=118$; mean difference: .53*) and of the "more spiritual" respondents opposed to the "equally" respondents in the US sample $(n=109$; mean difference: .32*). This reflects what we see from other calculations also: Faith development interview scores are generally higher for the "more spiritual" respondents, "more spiritual" respondents assemble rather at Stages Four and Five.

\footnotetext{
$3 *$ indicates significance at the .05 level. All scales in the questionnaire were answered on a 5-point Likert-type scale from "strongly disagree" to "strongly agree."
} 
In sum, self-identification of being "more spiritual than religious" in comparison to a "more religious than spiritual" self-identification in general is associated with higher openness for experience and greater openness for the other and the religion of the other, with a higher sense of personal growth, and respectively with lower agreement to authoritarian statements and to claims for absolute truth of one's own religion. Further, "more spiritual" self-identification generally appears to be associated with higher interview scores in faith development. The differences, of course, do not appear to be overwhelmingly high, but they indicate significant statistical trends based on samples of considerable size. Thus, these characteristics of spirituality stand on solid ground - and indicate a profile of what "spirituality" may signify for the respondents in our sample.

The second approach to the question of what "spiritual" self-identification signifies, is the semantic analysis which takes primarily qualitative avenues. We have initial, but not sufficient, semantic assessments from previous research (Zinnbauer et al. 1997; Greenwald \& Harder 2003) for the religious field in the U.S.A.; we have, however, no systematic analysis of the semantics of spirituality in Germany.

From our own data, we can present some insight from interview passages that address the topic of "spirituality" (a systematic and comprehensive analysis is being presented elsewhere: Keller, Csöff \& Streib, forthcoming). From a careful reading of faith development interviews - in which we have answers to the question 'Do you consider yourself a religious person?'-, we derive some results which can be summarized like this: "Spirituality" is characterized by "more spiritual" self-identifying research participants in the US as referring to a nonmaterial dimension of existence. "Spirituality" for them is embedded in personal experience. Further characteristics are flexibility and openness. "Spirituality" is furthermore understood as the universal core of all religions and tied to the purpose of human life. "Spirituality" can be associated with belief in a higher being or higher presence. "Spirituality" for the interviewees in the German sample is basically similar to the US interviewees' definition; differences are that Germans mention the importance of sharing these experiences and mention specific practices like meditation. Germans also feel the need to reject a negative cultural stereotype: They do not want to be called esoteric.

Details from this brief report from qualitative analysis are in accord with quantitative results. But we should note that we need more 
research — which leads to our concluding remarks about the perspectives on the future of spirituality research.

\section{Perspectives on the Future of Spirituality Research}

As a conclusion we contend that future research on religion without attention to "spirituality" appears like a contradiction and like wearing blinkers in regard to entire areas of the contemporary religious field. Previous research as well as our own powerfully demonstrate that "spirituality" is a term by which a growing number of people express their (quest for) deep and authentic 'religious' experiences in an open variety of forms, even when these people have no affiliation (any more) with a religious organization. For too long in the history of empirical research on religion, entire domains of 'lived religion' were neglected and marginalized by the primary attention for the priest and the institution of the priest. The questionnaires and scales that have been - and are being! - used in research reflect this clearly. This is changing and many in the field realize that it is time to include not only the prophet, but also the mystic. The theoretical perspectives have been there in the literature for decades, but large-scale surveys are the slowest to change. ${ }^{4}$ In the immediate future we need focused research including semantic assessment of "spirituality" in cross-cultural comparison, but also including inter-disciplinary approaches to the biographical, psychological, and socialization characteristics of this variant of 'lived religion' - which, to large an extent, is lived outside religious organizations.

\section{References}

Altemeyer, B. (1996). The Authoritarian Specter. Cambridge, MA: Harvard University Press.

Bourdieu, P. (1971). Genesis and Structure of the Religious Field. Comparative Social Research, 13 (1991), 1-44.

- (1987). Legitimation and Structured Interest in Weber's Sociology of Religion. In: S. Lash \& S. Whimster (Eds.), Max Weber, Rationality and Modernity (pp. 119-136). London: Allen \& Unwin.

${ }^{4}$ We therefore commend the inclusion, in the ISSP 2008 Religion Questionnaire, of a question such as "I don't follow a religion, but consider myself to be a spiritual person interested in the sacred or the supernatural" and look forward to the results. 
Costa, P. T. \& McGrae, R. R. (1985). Revised NEO Personality Inventory (NEO PI-R) and NEO Five-Factor-Inventory (NEO-FFI). Professional Manual. Odessa: Psychological Assessment Resources 1992.

Daiber, K.-F. (2002). Mysticism: Troeltsch's Third Type of Religious Collectivities. In: Social Compass, 49, 329-341.

Dinter, A., Heimbrock, H.-G., \& Söderblom, K. (Eds.) (2007). Einfïhrung in die Empirische Theologie. Göttingen: Vandehoeck\&Rupprecht.

Gebhardt, W. (2002). Signaturen der religiösen Gegenwartskultur. die Verszenung der Kirchen und die Eventisierung der Religion. In: W. Isenberg (Ed.), Orte für den Glauben. Die zukünftige Gestalt des Christentums in der säkularen Welt (pp. 9-23). Bensberg.

Greenwald, D. F. \& Harder, D. W. (2003). The Dimensions of Spirituality. In: Psychological Reports, 92, 975-980.

Hood, R. W. (1975). The Construction and Preliminary Validation of a Measure of Reported Mystical Experience. In: Fournal for the Scientific Study of Religion, 14, $29-41$

- (2006). The Common Core Thesis in the Study of Mysticism. In: P. McNamara (Ed.), Where God and Science Meet: How Brain and Evolutionary Studies Alter our Understanding of Religion, Vol. 3. Westport, Conn: Praeger Publishers.

Houtman, D. \& Aupers, S. (2007). The Spiritual Turn and the Decline of Tradition: The Spread of Post-Christian Spirituality in 14 Western Countries, 1981-2000. In: Fournal for the Scientific Study of Religion, 46, 305-320.

Keller, B., Csöff, R.-M., \& Streib, H. (2007). The Bielefeld-Based Cross-Cultural Research on Deconversion: Qualitative Results (Final Report, Vol. II) Contributions to Biographical Research in Religion, No. 4, Bielefeld: University of Bielefeld, Evangelische Theologie.[online at: http://rf.isert-network.com/docs_en/FinalReport-Vol.2Qualitative.pdf].

Keller, B., Csöff, R.-M., \& Streib, H. (forthcoming). Who Says 'I am more Spiritual than Religious'? 'More Spiritual' Self-Identifications and the Semantics of Spirituality in Qualitative Analysis.

Knoblauch, H. (2003). Europe and Invisible Religion. In: Social Compass, 50, 267-274.

Luckmann, T. (1967). The Invisible Religion. The Problem of Religion in Modern Society. New York: Macmillan.

Marler, P. L. \& Hadaway, C. K. (2002). 'Being Religious' or 'Being Spiritual' in America: A Zero-Sum Proposition? In: Fournal for the Scientific Study of Religion, 41, 289-300.

Ryff, C. D. \& Singer, B. H. (1996). Psychological Well-Being: Meaning, Measurement, and Implications for Psychotherapy Research. Psychotherapy and Psychosomatics, 65, $14-23$.

Schleiermacher, F. (1799). On Religion. Speeches to its Cultured Despisers. translated and edited by Richard Crouter. Cambridge: Cambridge University Press 1996.

Smith, W. C. (1963). The Meaning and End of Religion. Minneapolis: Fortress Press 1991.

— (1979). Faith and Belief. Princeton: Princeton University Press.

Streib, H. (1998). Alltagsreligion oder: Wie religiös ist der Alltag? Zur lebensweltlichen Verortung von Religion in praktisch-theologischem Interesse. In: International fournal for Practical Theology, 2, 23-51.

- (2007a). The Bielefeld-Based Cross-Cultural Research on Deconversion: Quantitative Results (Final Report, Vol. I) Contributions to Biographical Research in Religion, No. 3, Bielefeld: University of Bielefeld, Evangelische Theologie.[online at: http://rf.isertnetwork.com/docs_en/FinalReport-Vol.1-Quantitative.pdf].

- (2007b). Religious Praxis: De-Institutionalized? Theoretical and Empirical Considerations. In: H. Streib (Ed.), Religion inside and outside Traditional Institutions (pp. 147-174). Leiden: Brill. 
Thomas, G. (2001). Implizite Religion. Theoriegeschichtliche und theoretische Untersuchungen zum Problem ihrer Identifikation. Würzburg: Ergon.

Troeltsch, E. (1911). Das stoisch-christliche Naturrecht und das moderne profane Naturrecht. In: Verhandlungen des Ersten Deutschen Soziologentages (pp. 166-214). Tübingen: Mohr (Paul Siebeck).

. (1912). The Social Teaching of the Christian Churches, Vol. 2. London; New York: George Allen \& Unwin; MacMillan 1956.

Zinnbauer, B. J., Pargament, K. I., Cole, B., Rye, M. S., Butter, E. M., Belavich, T. G. et al. (1997). Religion and spirituality: Unfuzzying the fuzzy. In: Fournal for the Scientific Study of Religion, 36, 549-564. 